\title{
VII. ARTHUR HENDERSON, THE RUSSIAN REVOLUTION, AND THE RECONSTRUCTION OF THE LABOUR PARTY*
}

\author{
By J. M. WINTER
}

The Hebrew University of Jerusalem

THE dominant role of the secretary of the British Labour party, Arthur Henderson, in the reconstruction of the party in $1917-18$ has never been disputed. It is surprising, therefore, that little attention has been paid in recent historical literature to the development of Henderson's political ideas during the First World War and, more particularly, to the impact of the Russian Revolution on his attitude towards the conduct of international affairs and domestic politics. The neglect of this aspect of an important chapter of labour history has obscured the fact that Henderson came to advocate the reconstruction of the Labour party only after and partly as a result of his visit to Russia in mid-1917.

During the first three years of the war, Henderson's faith in the justice of the Allied cause and the necessity of total military victory over Germany was matched by a commitment to the old structure of the party of which he was the unchallenged war time leader. But after his mission to Petrograd on behalf of the British Government in June and July 1917, Henderson's approach to peace negotiations, his views on international socialism, and his ideas about Labour's political identity had completely changed.

On I August 1917, one week after he had returned to England, Henderson was kept waiting for an hour outside the doors of a cabinet meeting while his colleagues discussed his recent activities in promoting the idea of, and assisting in the arrangements for, the proposed conference of socialist parties at Stockholm. ${ }^{1}$ Most historians have conveniently chosen this 'doormat incident' as the turning point both in Henderson's political career and in the subsequent history of the Labour party. ${ }^{2}$ There was, however, far more to Henderson's

* I would like to thank the following people for their criticisms of earlier drafts of this article: Dr H. M. Pelling, Dr R. Miliband, Dr R. MacLeod, Professor G. Simpson, Mr R. Dare, and the members of Dr Kitson Clark's seminar at Cambridge. It is more difficult to acknowledge fully the debt I owe to the late Professor D. M. Joslin of the University of Cambridge, whose untimely death has deprived us of a kind counsellor. The research on which this article is based would never have been completed without his assistance.

1 The best discussion of the Stockholm Conference is Hildemarie Meynell, 'The Stockholm Conference of 1917 ', International Review of Social History (1960), Pp. I-25, 202-25.

2 H. M. Pelling, $A$ Short History of the Labour Party (196I), Pp. 41-2; G. D. H. Cole, A History of the Labour Party from 1914 (1949), p. 36 , recently reprinted in The Left and War: The British Labour Party and World War I, ed. P. Stansky (1969); and S. H. Beer, Modern British Politics 
attitude in August 1917 than a mere reaction to an admittedly crude political and personal snub. We will find the immediate origins of his new political outlook only if we look elsewhere, that is, to Russia in the early days of the socialist revolution.

\section{Introduction}

Arthur Henderson was fifty-four years old at the time of the first Russian Revolution. He was then one of the most important political figures in Britain: one of Lloyd George's War Cabinet of five and the leading spokesman of the working class among the mighty. His personal standing among the rank-andfile of the labour movement was second to none.

He had risen to a position of prominence in the pre-war decade as a trade unionist and as one of the first Labour members of parliament. To a great degree, his political importance was a direct result of his identification with the predominantly non-socialist craft union wing of the organized labour movement.

His early political views, along with those of many of his colleagues, were indistinguishable from non-conformist Liberalism. ${ }^{3}$ In fact, before the First World War, his work in the Labour party was almost always at odds with its socialist section. His cautiousness and conservative attitude as chairman of the parliamentary Labour party in 1908-10 and as party secretary from I9II on were repeatedly and severely criticized by the socialists of the Independent Labour party. It was no secret that the consolidation of the party's vulnerable political position was of far greater concern to him at this time than the promotion of progressive policies. Indeed it makes very little sense to describe Henderson's pre-war political views as socialist in any but the broadest sense of the term. In this respect, he was undoubtedly representative of the vast majority of the party.

Despite its refusal to adopt a socialist programme, the Labour party had been admitted to the International Socialist Congress in 1908, for the stated reason that

(1966), pp. I44-52, which relies heavily on Cole's account. All books cited are published in London unless otherwise noted.

3 In a survey of the twenty-nine new Labour M.P.s in 1906, Henderson stated that the book which had influenced him most was Wesley's Sermons. Cf. 'The Labour Party and the Books that Helped to Make It ', Review of Reviews (June 1906), pp. 568-82. His first political experience was as a Liberal member of the Newcastle-upon-Tyne Town Council. He also served for seven years as election agent of the Liberal M.P. Sir Joseph Pease, the chairman of the North-Eastern Railway. When Pease retired from politics in 1903, Henderson decided to stand for the vacated seat in the Durham constituency of Barnard Castle. On instructions from his union, the National Society of Ironfounders, which financed his candidacy, he broke with his political past and ran as a member of the Labour representation committee. He won in a three-cornered fight by forty-seven votes, and was re-elected comfortably three years later. Cf. F. Bealey and H. M. Pelling, Labour and Politics 1900-1906 (1958), pp. 152-5; P. Poirier, The Advent of the Labour Party (1958), pp. 196206; H. M. Pelling, Social Geography of British Elections 1885-19Io (1967), p. 337 . 
although it does not avowedly recognize the class struggle, it actually carries it on; and because the organization of the Labour Party, being independent of the bourgeois parties, is based upon the class struggle. ${ }^{4}$

As party secretary, Henderson was entitled to serve as secretary of the British section of the International. But since he had never been a member of any socialist body, there was some doubt about his eligibility for the post. He therefore decided to join the Fabian Society in 1912, an act which illustrates well the purely formal and tenuous link between Henderson's pre-war political activity and any serious commitment to socialism. ${ }^{5}$

In the early days of August 1914, when the question of peace or war was still in the balance, Henderson decided to try to mobilize the forces of organized labour at first in favour of neutrality and then in unwavering support of the Allied cause. On 4 August $19 \mathrm{I}_{4}$ he wrote to the members of the Labour party National Executive Committee (NEC) to call a special meeting at ro a.m. the next day 'to consider what action should be taken in the very serious crisis in Europe and any other business that may arise'. He also suggested that a conference of Labour leaders be convened at the House of Commons at 2 p.m. the same day 'for the purpose of considering the formation of a National Peace Emergency Committee...', the purpose of which would be 'To urge the strictest neutrality possible in the present crisis. ${ }^{\prime}$ Henderson envisaged an organization of unprecedented size and representation, which would have constituted a parliament of Labour. Besides the full Labour party NEC, the parliamentary committee of the Trades Union Congress, and the management committee of the General Federation of Trade Unions, the Peace Emergency Committee would also have included three members each from fifteen major labour and socialist bodies. ${ }^{7}$

The idea of a labour peace group did not even outlive the day of its inception. The invasion of Belgium and the subsequent British declaration of war on Germany abruptly ended all attempts to promote neutrality. From that moment on, Henderson and most other Labour leaders placed the success of the war effort before all other considerations. The Peace Emergency Committee immediately became the War Emergency Committee, with the object of helping 'to mitigate the destitution which will inevitably overtake our working people whilst the state of war lasts '. ${ }^{8}$

When the Labour party NEC met during the afternoon of 5 August, it approved by a majority vote support for British entry into the war, while at

4 British Library of Political and Economic Science, 'The Infancy of the Labour Party ', II, 94, text of resolution passed by International Socialist Bureau, 12 Oct. 1908.

5 Pelling, A Short History of the Labour Party, p. 32.

- Labour party library, War Emergency Committee Papers, Box : From Conference to Conference, Text of proposed objects and membership of Peace Emergency Committee.

7 Ibid.

8 War Emergency Committee Papers, Box : From War to War Office, Circular signed by W. C. Anderson and Henderson on behalf of the Labour party, 6 Aug. 19r4. 
the same time declaring its opposition to the policy of the balance of power which produced it. The war resolution pledged the party leadership to the task of working 'to secure peace at the earliest possible moment on such conditions as will provide the best opportunities for the re-establishment of the amicable feelings between the workers of Europe '.${ }^{9}$ Later in the war, this phrase took on a different meaning but, initially, it implied only that Germany had to be defeated by every available means. To this end, Henderson was prepared to accept on behalf of the Labour party virtually any personal or political sacrifice. He was the first to insist, in the name of national unity, that Labour had to place its fate in the hands of the Asquith government. By the evening of 5 August, the political truce was on.

This policy of voluntary renunciation of political independence for the sake of military victory culminated nine months later in Henderson's acceptance of Asquith's offer to the Labour party 'to associate' in a coalition government. Although a majority of the parliamentary party opposed entry into the government, Henderson and almost the entire NEC were strongly in favour. On a joint vote, therefore, the proposal to join the coalition was passed, seventeen to eleven. ${ }^{10} \mathrm{He}$ thus became the first Labour M.P. in a British Government, serving initially as President of the Board of Education and after August I9r6 as paymaster-general with a seat in the cabinet. Four months later, the NEC ratified Henderson's agreement to join Lloyd George's War Cabinet. ${ }^{11}$ Officially he was appointed minister without portfolio, but he acted consistently as the government's intermediary with the unions and its specialist on industrial problems.

Even before he had accepted government office in May 1915, he had been instrumental in arranging the Treasury Agreement of March of that year, whereby most of the trade union movement agreed to renounce strike action and to relax trade practices for the duration. In the following months, he spent much of his time seeing that the numerous conflicts and difficulties which were bound to arise in industry did not interfere in any important way with war production. Henderson's enormous prestige among organized labour did much to ensure the overall success of his work as Lloyd George's chief industrial conciliator and, as such, he fulfilled a vital political mission.

\section{1917 : Before Petrograd}

Until mid-rgr7, Henderson retained his old political outlook and managed, though with increasing difficulty, to maintain his dual loyalty to the coalition government and to his party. At first he was completely unresponsive to the growing mood of discontent within the Labour party about the conduct of the war effort, both at home and at the front. Similarly, Henderson's opinion of

\footnotetext{
9 Labour party library, Labour party NEC minutes, 5 Aug. 1914. The vote was 8-4.

10 Labour party NEC minutes, I9 May I915.

11 Labour party NEC minutes, 7 Dec. 1916.
} 
any change in the federal structure and non-ideological basis of the party was distinctly negative before his visit to Russia.

At the Manchester conference of the Labour party in January 1917, W. Frank Purdy of the Shipwright's Union, the party chairman, claimed that it

has steadily, and, in my opinion, wisely, always declined to be bound by any programme, or to subscribe to any dogma, or to lay down any creed. It has refused to adopt any mechanical formulas or to submit to any regimentation either of ideas or of policy. ${ }^{12}$

Henderson's viewpoint at this time was similarly conservative. When a resolution was moved to force the Labour party NEC to remove a candidate from the official party list if he was repudiated by an affiliated organization, he asked on behalf of the executive for the rejection of the proposal for the reason " that the present was not the time for tinkering with the Constitution.${ }^{13} \mathrm{He}$ also opposed a resolution to reorganize the executive on the grounds that the party had been built up through the old constitution and, therefore, he was extremely reluctant to change it. "When organizations were invited in under a particular Constitution', he pointed out, 'the greatest care ought to be exercised before any alteration was made in it.' ${ }^{14}$

The 1917 conference was also significant in the surprisingly hostile reception Henderson received during the discussion of the deportation of militant trade unionists on the Clyde. He was accused by one of the deportees, David Kirkwood, of having lost the confidence of labour by his association with Lloyd George and the repressive measures he had authorized to silence dissenters. ${ }^{15}$ While trying to defend himself despite numerous interruptions, Henderson remarked that he never had been the target of such heckling, and that he knew that 'the Conference was not in that frame of mind to do justice to men like himself'. He told the irate delegates that he was fully conscious of the difficulties he faced in trying to reconcile his post as party secretary with cabinet office, and, furthermore, he had had no part in the deportations. To cries of 'resign ' from the government, he replied bitterly,

If he had to resign he would be resigning every day to please some of them. He was not sure he would not resign if he were to please himself, but he was not there [in the Cabinet] either to please himself or them, he was there to see the War through. ${ }^{16}$

And with that patriotic assurance and a promise to look into the matter, he weathered at least that storm of criticism.

Henderson was also exposed to equal pressure for loyalty from his cabinet colleagues. One of his most important functions was to keep the government informed about the state of Labour opinion both in Britain and, when possible, on the continent. He dutifully reported to the cabinet his impressions of the

12 Labour Party Annual Report, I917, p. 82.

13 Ibid. p. 137 .

14 Ibid.

15 Ibid. p. 105 .

16 Ibid. pp. Io6, I Io. 
1917 Labour party conference ${ }^{17}$ and, earlier in January, he told of his reactions to a conference of Allied socialists in Paris 'at which it was clear that there is a considerable development of pacifist feeling'. He noted optimistically, though, that the conference was 'satisfactory' since the socialists were still resolved 'to assist the Governments in the prosecution of the war'. ${ }^{18}$

The February Revolution in Russia added a new set of problems to the Allied war effort. The foreign policy of the deposed tsar was completely acceptable to the British government, but no one knew for certain if the new provisional government in Petrograd would maintain it. Henderson and the rest of the cabinet were horrified by the possibility that internal disorder could lead to the collapse of the Eastern Front. Anyone could see that the consequences of an interruption of Russia's contribution to the fight against the Central Powers, let alone her unilateral withdrawal from the war, would be staggering to the Allies. Enormous additional pressure would be brought to bear on the armies in the west. Some way had to be found in the early spring of 1917 to convince the Russian socialists and liberals to continue the struggle.

The cabinet were therefore happy to hear from Henderson in late March that he had received a note from a group of French socialists who were in England en route to Petrograd ' to persuade' the Russian socialist party ' to do all in its power to bring the war to a satisfactory conclusion'. Henderson was instructed to get a 'suitably composed British Labour Deputation [to] accompany the French party with the same object'.${ }^{19} \mathrm{~W}$. S. Sanders, Will Thorne and James O'Grady agreed to go, and the two delegations proceeded to Russia. ${ }^{20}$

At about the same time, the fall of the tsar had rekindled hopes among some European socialists that they were now in a position, on account of the Russian Revolution and the attitude of its leaders, to launch a peace offensive. On 24 April 1917, Henderson received a telegram from Camille Huysmans, the Belgian secretary of the International Socialist Bureau, informing him that the Dutch section were going to convene at Stockholm a special meeting of the European socialist parties affiliated to it. The conference was tentatively scheduled for 15 May 1917. Henderson knew that the French socialist party executive were against such a conference, which German and Austrian socialists were likely to attend. He therefore had little difficulty in persuading the Labour party executive on 9 May to pass a resolution 'that the British Labour Party should not be represented at the Stockholm Conference '. ${ }^{21}$ Instead, Henderson moved 'That a Conference of the Socialist Parties in the Allied Countries (Belgium, France, Russia, Italy, the United States, and Great Britain) should be held in London as early as possible' and furthermore

17 P.R.O., Cabinet Papers [hereafter referred to as 'Cab'] 23/x, no. 47 (Io), 29 Jan. 1917.

18 Cab. 23/r, no. 25 (4), 2 Jan. I9I7.

19 Cab. 23/2, no. 104 (5), 26 Mar. 1917.

20 Cab. 23/2, no. 107 (9), 28 Mar. 1917.

21 Labour party NEC minutes, 9 May 1917. The vote was 9-4. 
that a British Deputation be appointed to proceed to Russia for the purpose of consulting with the Russian Council of Workmen's and Soldiers' Delegates with a view to urging them to send representatives to the proposed London Conference.

The provisional date for this alternative meeting was set for the week ending 23 June 1917. Purdy, G. H. Roberts, and Henderson agreed to go to Russia to persuade the Russians to come to London rather than Stockholm. ${ }^{22}$

Henderson reported these developments to the cabinet two days later, and explained that his party executive had agreed 'to send a Mission to Petrograd to impress on the Russian Socialists the danger of a separate peace'. ${ }^{23}$ The cabinet expressed reluctance to let Henderson leave the country in view of the growing industrial unrest in Britain. But the under-secretary for foreign affairs, Lord Robert Cecil, convinced them on 2I May that it was essential for Henderson to go to Russia on a mission parallel to that of $\mathrm{M}$ Albert Thomas, the French socialist minister of munitions who had replaced the ambassador, $\mathbf{M}$ Paléologue. ${ }^{24}$ On 23 May the cabinet decided that the British Ambassador, Sir George Buchanan, was 'no longer the ideal British representative' in Petrograd on account of his close association, like Paléologue, with the tsarist regime. It was also agreed that

The British representative in Petrograd should be a person calculated to exercise a powerful influence on the democratic elements which now predominate in Russia to pursue the war with energy. They therefore invited Mr Arthur Henderson to make a personal sacrifice and go to Petrograd on a similar footing to that of $\mathrm{M}$ Albert Thomas. ${ }^{25}$

No decision was taken on the length of his stay, only that it would be 'temporary ${ }^{\prime 26}$ Henderson agreed to the proposal and, with his mind set against the Stockholm Conference, he left the next day for Russia. ${ }^{27}$

22 Cab. 23/2, no. 136 (15), II May 1917. Ultimately Purdy withdrew from the deputation because he objected to being associated with ILP-men like MacDonald and Jowett, who were also invited to Russia as minority delegates. Roberts declined to go for the reason that ' as a member of the Government his inclusion in the Executive deputation might lead to misunderstanding '. They were replaced by Hutchinson and Clynes, who both later changed their minds. Finally Roberts reversed his decision after consultation with the cabinet, and Carter joined him along with MacDonald and Jowett for the ILP and Julius West for the Fabian Society. But when they got to Aberdeen, with government permission to do, Havelock Wilson's National Sailors' and Firemen's Union refused to service a ship carrying known pacifists en route, they thought, to consultations with the Germans, who had just begun their policy of unrestricted submarine warfare. Henderson's intervention was in vain. The boat left without the Labour delegates, who agreed to go together or not at all. Cf. Labour party NEC minutes, I June, 7 June, 20 June i9i7.

23 Cab. 23/2, no. $13^{6}$ (15), ir May 1917.

24 Cab. 23/2, no. 14I (15), 21 May 1917.

25 Cab. 23/2, no. 144 (I), 23 May 1917.

26 Ibid.

27 Labour party NEC minutes, I June 1917. Arno Mayer, in his Political Origins of the New Diplomacy 1917-1918 (New Haven, Conn., 1959), p. 215, is wrong when he claims that 'at the time of his departure [for Russia], Henderson was still uncommitted on the Stockholm question'. 


\section{The Impact of Russia}

Henderson arrived in Russia on $\mathrm{r}$ June $1917,{ }^{28}$ without any idea of the magnitude of the problems which confronted the provisional government. His ignorance of the Russian language and his inexperience in foreign affairs left him at first completely in the hands of Sir George Buchanan, the man whom ostensibly he had been sent to replace. Henderson respected his views and could not see any advantage in his departure from Petrograd. Their relationship developed along the lines of mutual respect and trust, and Henderson was given every assistance in his effort to begin to untangle the very complex strands of the Russian political situation. ${ }^{29}$

He quickly learned of the circumstances surrounding the resignation two weeks previously of the foreign secretary of the first provisional government, Paul Miliukov, who was a leader of the Liberal cadet party and an exponent of both all-out war against Germany and the adoption despite the revolution of the annexationist policies of the tsarist regime. His political demise was a victory for the relatively moderate Menshevik socialist leaders of the Petrograd Soviet of Workers' and Soldiers' Deputies, which held political power effectively but not officially after the February Revolution, and whose spokesmen now dominated the provisional government as well. While Prince Lvov remained titular head of the new government, among the socialists Alexander Kerensky became minister of war and Irakli Tsereteli minister of posts. The Liberals could not yet be ignored, however, and the portfolio of foreign affairs went to Michael Tereshchenko, a widely-travelled millionaire who had been minister of finance in the previous coalition. ${ }^{30}$

The new provisional government adopted the two-part peace policy of the Petrograd Soviet: to press for a general peace without annexations and at the same time to defend the homeland and the revolution against foreign invaders. This appeal to both pacifists and patriots was popularly known as Revolutionary Defencism, the outlines of which had been sketched by Tsereteli and other Mensheviks during their pre-1917 exile. ${ }^{31}$ In the spring of that year, this plan seemed to provide the way for Russia to begin to disengage from a war which she could not continue indefinitely.

The success of Revolutionary Defencism depended on the one hand on the participation of the Allied socialists in the proposed Stockholm Conference. The military situation was the other determinant of foreign policy at the beginning of June 1917. At that time, the Russian Government hoped that this

28 'Mr. Henderson in Russia', The Times, 2 June 19r7. The Russian use of the Julian calendar, which was thirteen days behind the Gregorian calendar used in the west, meant that Henderson arrived in Russia on 19 May, their time. I have used the western dating throughout.

29 Sir George Buchanan, My Mission to Russia (1923), I, 144 ff.; Mary Agnes Hamilton, Arthur Henderson (1938), p. 126.

30 Rex Wade, The Russian Search for Peace (Stanford, Calif., 1969), chs. II, IIr.

31 Rex Wade, 'Irakli Tsereteli and Siberian Zimmerwaldism', Journal of Modern History (Dec. 1967), pp. 425-43I. 
assembly of socialists would mobilize western public opinion in such a way that the respective governments would be forced to move towards a negotiated settlement. While Henderson was en route to Petrograd, Buchanan had an interview with Tsereteli, in which the latter

said that it was necessary that Allied Democracies should come to complete agreement on the subject of the aims of the war and of eventual Peace Terms ... He (further?) dwelt on necessity for maintaining closest contact between British and Russian Democracies by means of exchange of visits between representatives of the various Labour and Socialist groups in each country. ${ }^{32}$

The British ambassador had further assured Tsereteli that the Russian Revolution 'was likely to bring views of British and Russian democracies into closer harmony more especially as regards the war '. ${ }^{3 s}$ Thus Henderson's presence in Petrograd seemed to be an excellent opportunity to enlist the support of a powerful western labour leader on an issue which the Russian socialists in power rightly saw as crucial to their political survival. If the Mensheviks and their Allies could not extricate their country from the war, there were others, as Lenin had made plain in his April theses, who would act to end the slaughter. ${ }^{34}$

In the first weeks of his mission, Henderson quickly recognized the precariousness of the Russian situation, but it took him somewhat longer to decide that the Allies and in particular the Allied socialists had to act in concert to keep the regime alive. His support for the aims of the February Revolution was complete, but about a month passed before he saw that for the new leaders of Russia the alternative to peace was political disaster.

The Petrograd correspondent of The Times noted in a dispatch dated 6 June I917 that 'Mr Henderson's visit coincides with a labour crisis here, and will certainly be helpful to the Provisional government ${ }^{.35}$ When he attended a meeting of the council of ministers in Petrograd in early June, Henderson was told by Prince Lvov that Russia was undergoing ' in industry [the] destructive stage of [the] revolution...' The prime minister added that his government wanted to make full use of his knowledge of industrial affairs, and to this end Skobelev, the minister of labour, invited him to come to his office and to consider it his headquarters. ${ }^{36}$

Henderson informed Lloyd George of this meeting and of Prince Lvov's view that 'as [the] Government gain in strength all classes were beginning to realize existence of an authority in the state superior to both capital and labour'. But he learned at the same time that 'Extremist propaganda was causing [the] Government much anxiety, worst offenders being found among returning

32 P.R.O., Foreign Office Papers (hereafter referred to as 'F.O.'), 37r/30ro, Buchanan's cable on his interview, dated 27 May 1917.

33 Ibid.

34 Wade, The Russian Search for Peace, ch. Iv.

35 'Mr Henderson's Mission', The Times, 6 June 1917.

36 Ibid., and F.O. Papers, 371/3010, cable of Henderson to Lloyd George, 8 June I9I7. 
exiles '. ${ }^{37}$ The Bolshevik danger was clearly a crucial factor in an appreciation of Russian affairs.

Henderson was perfectly prepared to help counteract the revolutionary defeatist propaganda of the Bolsheviks and their allies. He agreed to address various groups of Russian workers in an attempt to transmit to them the enthusiasm of their British counterparts for the war effort. On 15 June he spoke to a crowd of over 5,000 workers and soldiers assembled at the People's Palace in Petrograd. We can get some idea of the intended, if not actual, effect of Henderson's visit on public morale from The Times report of his speech:

His reference to the unanimous determination of all classes in the British empire to continue the struggle till a victorious peace had been assured evoked tremendous cheering. He spoke of his own personal share in the war. When he told the audience that his eldest son was among those who had fallen on the battlefield the whole audience rose and sang the Russian Requiem.

At the conclusion of the speech there was a scene of indescribable enthusiasm. Men and women, moved to tears, demanded a general mobilization, amid cries of: 'We all are ready to march against the foe.' ${ }^{38}$

Few have claimed that Henderson was a powerful orator, and The Times correspondent, Robert Wilton, who was fiercely anti-Bolshevik, ${ }^{39}$ was undoubtedly carried away here by his prose. But it is hardly surprising that those opposed to the continuation of the war completely distrusted Henderson and his mission.

The Bolsheviks did not hide their contempt both for the Stockholm idea and for Henderson himself. Lenin called the preparations for the conference a ' comedy' growing out of 'the political manoeuvres of German imperialism'. The Germans were only interested in discussing peace terms with the Allied ' social chauvinists', he claimed, because they were beginning to see by July 1917 that 'to carry on the war now is a hopeless task '.40 A speech reported in Pravda denounced Stockholm in stronger terms, and further indicted Henderson as one of those deluded majority socialists who

are partisans of the ' union sacrée ' of classes, a principle forged by the enemies of the working class who have ensnared to their side the labour aristocracy. Whoever extends his hand to Henderson or to Thomas, extends it as well to Lloyd George and Ribot, to the English and French bankers. ${ }^{41}$

On I4 June, Henderson's Petrograd apartment was ransacked and his personal documents were taken. Wilton of The Times concluded that the Bolshe-

37 Ibid.

38 'American Mission in Petrograd ', The Times, 18 June 1917.

39 Cf. Robert Wilton, Russia's Agony (1918), passim for a full statement of his anti-Semitic and anti-Bolshevik attitudes.

40 V. I. Lenin, British Labour and British Imperialism (1969), pp. I72-3. Cited from Collected Works (Moscow, 1934), xx, Bk. i, 287-90.

« Marc Ferro, La Révolution de 1917 (Paris, 1967), p. 352, citing Pravda of 8-21 June 1917. The English translation is mine. Cf. also Zinoviev's speech to the Petrograd Soviet on 16 June, cited in G. H. Gankin and H. H. Fisher, The Bolsheviks and the World War (Stanford, 1940), Pp. 623-6. 
viks were responsible. He reasoned that Henderson's statements sounded so much like British propaganda that 'The Leninists... stole his papers - to ascertain whether he was really a Socialist leader or merely an agent of the British Government,...' He added that

their myrmidons also took his clothes, which was excusable, in as much as the members of the Soviet were suffering from a shortage of garments due to the decreased output of the textile mills. ${ }^{42}$

But regardless of who was to blame in this minor incident, Henderson was aware of the Bolsheviks' hostility to him. He also knew that very little could be taken for granted in Russia, not even the personal security of a distinguished guest of State.

A visit to Moscow at the end of June did not alter Henderson's impression of the confusion and gravity of the political situation. In his public pronouncements he tried to bolster the government's position by pointing out to employers and employees that the failure of moderate socialist leadership would lead inevitably to the victory of the extremists. At a meeting of the Moscow bourse committee, he described the operation and advantages of State control of industry in war-time. The following day, he intervened successfully in an industrial dispute which had involved Welsh tinplate workers on loan to a Moscow factory. ${ }^{43} \mathrm{He}$ even persuaded the Nevsky Thread Company, which was backed by British investors, to agree to the transfer of control of their works to the government for the duration. ${ }^{44}$ Still, his pessimism deepened.

At the end of his visit, he cabled Lloyd George that 'I am afraid I have brought back [from Moscow] an even less cheerful view of position than I had formed in Petrograd.' ${ }^{45} \mathrm{He}$ told the prime minister of his speech to the British colony there in which he urged the ' necessity for supporting Provisional Government ' to prevent worse things from happening. On a brighter note, he added

I have noticed a distinctly more reasonable tone appearing in conversation with business men since I have been here. One hears less of closing down to give Socialists a lesson. Employers are beginning to realize only safeguard against control of workmen is control by State ...46

Henderson admitted being appalled, though, by the 'complete absence both of machinery of traditional (?) [sic] collective negotiation and of administrative experience in Government ' and therefore ended his cable to Lloyd George with this prediction: 'you must anticipate such a reduction in productive capacity of Russia as will not far remove it from complete collapse.' 47

42 'Imperial and Foreign News Items', The Times, I4 June 1917; and Wilton's letter to the editor of The Times, 3I Dec. 1917, signed 'Petrograd Correspondent'.

43 'Mr Henderson in Moscow', Daily Chronicle, 3 July r917.

44 F.O. Papers, 371/2997, cable of Buchanan to F.O., 5 July 1917.

45 F.O. Papers, 37x/2997, Henderson to Lloyd George, I July 1917.

46 Ibid.

17 Ibid. 
His despondency was not relieved by a meeting with the Moscow Soldiers' Council, which the acting consul-general, Bruce Lockhart, had arranged. Henderson addressed this body and learned first-hand of the suspicion in which British war aims and the Allied cause were held by many Russian socialists. ${ }^{48}$ Their hostile reception and a subsequent discussion with the President of the Soldiers' Council, Urnof, confirmed Henderson's fears about the consequences of the failure of the friendly provisional government. Urnof 'explained frankly', Henderson wrote,

that Russia was sick of the war and industrial exhaustion. National feeling hardly existed but at the same time there was even in masses a sentiment of honour which made idea of separate peace distasteful. To create out of this feeling real enthusiasm for war in the people and army was the task of his party and it was rendered very difficult by refusal of Allies to accept without reserve platform of Russian (?Socialists) ... he added rather naively that what in particular made views of British Labour on war suspicious to his friends was that they seemed to coincide with those held by Russians of middle class. ${ }^{49}$

\section{Lockhart told Buchanan of Henderson's reply}

that the English workers had their own point of view about the war, that they were in no way influenced by the Russian bourgeoisie, and that if the Russian bourgeoisie held the same point of view as the English workers the latter were not to blame. ${ }^{50}$

The consul wryly noted that it was 'difficult to explain in a dispatch the unfortunate effect which such an answer produced'. The interview 'was certainly not one of the most striking successes of Mr Henderson's mission', and it showed 'how far removed' his thinking was from that of moderate Russian socialists, let alone from that of Lenin and his colleagues. ${ }^{51}$ Lockhart added that his visit did

serve to encourage the bourgeoisie and pro-war elements. In view of the bitter class hatred which is being propagated in Russia at present, it is a matter of conjecture whether such encouragement is a real benefit or not. ${ }^{52}$

Recalling that meeting in later years, Lockhart wrote of Henderson: 'The comrades in the Soviets bewildered him. He did not understand their language. He did not like their manners.' And ' whatever its effect on the Russians', his exposure to the views of even patriotic, anti-German men like Urnof 'had the advantage of curing $\mathrm{Mr}$ Henderson of any revolutionary tendencies for the rest of his life '. ${ }^{53}$ There is some question as to whether he needed a cure in the first place, but there is no doubt that he was not only thrilled but also appalled by the prospects of the Russian Revolution.

48 F.O. Papers, 438/10, letter of Lockhart to Buchanan, 23 July 1917. A copy of Henderson's speech and the reaction of his audience may be found in A. J. Sack, The Birth of the Russian Democracy (New York, 1918), pp. 374-6.

49 F.O. Papers, 371/2997, Henderson to Lloyd George, I July 1917.

50 F.O. Papers, $438 / 10$, Lockhart to Buchanan, 23 July 1917.

51 Ibid.

52 F.O. Papers, 371/2997, Lockhart to Buchanan, 3 July 1917.

53 R. H. Bruce Lockhart, Memoirs of a British Agent (1932), pp. 187, 188. 
In any event, the turmoil which swept through Russia in mid-19r7 was, in Henderson's opinion, certainly bound to diminish her contribution to the Allied war effort. On I July 1917, he wrote to Lloyd George that the conclusion which I draw from a month's observation is that Russia can no longer be regarded as effective Ally... Therefore we must make up our minds to continue the struggle alone with France and America carrying Russia with us as an inert partner... ${ }^{54}$

This view did not imply that he was indifferent to the political complexion of the Petrograd Government, as Lloyd George may have gathered from his repeatedly pessimistic dispatches. On the contrary, Henderson still believed that even a crippled partner ruled by men sympathetic to the Allied cause and western democracy was far preferable to a Bolshevik Russia which would undoubtedly sue for a separate peace at the first opportunity. To help forestall this unwelcome change, Henderson decided in early July to support the Stockholm Conference.

\section{The Stockholm Question}

The evolution of Henderson's viewpoint on Stockholm paralleled his growing doubts about the industrial outlook in Russia. In the early days of his visit, he joined Thomas and the Belgian socialist Vandervelde in opposing an international conference of socialists without prior agreement on issues such as Alsace-Lorraine and reparations which they knew the Germans could not accept. ${ }^{55}$ Henderson cabled the Foreign Office on 8 June that the proposed binding conference of all belligerent parties was 'most objectionable'. ${ }^{\text {s6 }}$ Three days later, he told the Petrograd Soviet that a settlement of the issue of the war would be 'fully and frankly dealt with by the representatives of the Allied nations assembled at the Peace Conference' and not at Stockholm. ${ }^{57}$ On 17 June he warned the same body:

We must be careful; because our choice to-day may be between honour and infamy; an untimely peace and years of fear; a few months of fighting and suffering and a lasting peace. These are, I think, the views of the overwhelming majority of the organized workers of Great Britain. ${ }^{58}$

In fact, Henderson even went further and shocked his Russian colleagues by stating that it was British Labour, and not the government or its representatives

54 F.O. Papers, 371/2997, Henderson to Lloyd George, I July 1917 .

35 'Socialist Peace Terms', The Times, 7 June 1917. Text of letter dated 4 June to Petrograd Council: "We are more than ever convinced that a plenary meeting to which would be admitted those who are supporting the present policy of the Majority Socialists in the Central Powers would be harmful and dangerous and would leave the doubt that a just and permanent peace is possible before the imperialism of aggression has been destroyed.'

56 Labour party NEC minutes, 20 June 1917. He reiterated his opposition in a cable of 17 June.

57 ' New Allied Note to Russia', The Times, 8 June; 'The French Reply to Russia', The Times, 9 June rgry.

58 'Duma Speaks Out', The Times, I8 June r917. 
like Buchanan, which opposed Stockholm. In conversation with Tsereteli, he remarked :

In order to understand the difference between my attitude and Buchanan's, it is necessary to remember that if we decide to go to Stockholm, then the pleasure of meeting the Germans will be mine and not Buchanan's. ${ }^{59}$

By early July, however, Henderson's fears about the weakness of the provisional government led him to soften and then to reverse his previous opposition to participation in the Stockholm Conference. He never wavered, though, in his determination to see an Allied victory over Germany, and he came to support Stockholm only when he was convinced it would not lead to an Allied capitulation.

In a cable to Lloyd George at the beginning of July, Henderson insisted that 'we must be on our guard ' against any

appearance of coldness or neglect in our dealing with Provisional Government. Anything which injures their credit here can only operate to strengthen forces of disorder and to postpone the Restoration of Russia. ${ }^{60}$

He pointed out that there were two currents of opinion in Russia about the way to achieve peace.

One is for direct action on Western proletariate to provoke uprising against capitalism and war together. The other is for Constitutional action by first converting labour and (?Social)ist parties and then trusting to pressure they will exercise on the Government. ${ }^{11}$

The first view was the Bolshevik, the second the Menshevik; and, Henderson concluded, the same distinction existed between the 'agitator and idealist in all countries '. 22 His firm support for the 'idealist' provisional government eventually brought him to favour the Stockholm project.

The event which sealed Henderson's change of mind about the conference was the ill-fated Kornilov offensive, which was launched at the beginning of July to re-establish Russia's political standing among her Allies. After the Russian army had begun to disintegrate and the offensive turned into a rout, he came to see that support for Stockholm was probably the only way to keep Russia in the war and to keep a moderate government in power. ${ }^{63}$ He knew that Tsereteli and Skobelev were determined to see that the conference was convened, whether British Labour attended or not, and that the idea of Stockholm was extremely popular in Russia. In addition to accepting the inevitable,

59 Cited in Wade, The Russian Search for Peace, p. 59. His source was a passage in Tsereteli's memoirs, also cited in Ferro, La Revolution de 1917, p. 362 .

6o F.O. Papers, 371/2997, Henderson to Lloyd George, I July 1917.

61 Ibid.

62 Ibid.

63 Buchanan's opinion was similar. He cabled the Foreign Office on 5 July: 'Nothing would 1 think help Kerenski so much at the present moment as announcement that Allied Government had accepted Russian proposal for Conference in early September.' F.O. Papers, 371/2997. 
he hoped that participation in an international socialist assembly would help clarify British war aims and thereby refute the Bolshevik propaganda about the imperialistic nature of the war.

Given the available options, Henderson was prepared, after six weeks in Russia, to accept participation in the Stockholm Conference. Before he left Petrograd on 16 July he even suggested the 'temporary relinquishment' of government office for delegates, so that the most prominent Labour leaders could attend. In Stockholm the next day, he discussed the subject further with the Swedish socialist Hjalmar Branting, and urged a further delay in convening the conference beyond the proposed date of 15 August. The reason he gave was that the project really involved little less than the reconstruction of the socialist international 'from the bottom ' ${ }^{64}$ His dedication to this task was a direct outcome of his visit to Russia.

Henderson's change of mind about Stockholm shocked at least one man who had known him in Russia. Robert Wilton of The Times wrote bitterly six months after Henderson's visit:

He came to Petrograd a convinced opponent of the Stockholm Conference idea ... He expressed his disapproval of the underhand manner in which the invitation to this Conference had been issued by the Soviets. He even spoke rather strongly about the Russian Revolutionaries in general. But instead of his 'converting' them, they 'converted ' him. ${ }^{65}$

Stripped of its pejorative tone, Wilton's judgement is correct. Arthur Henderson experienced a type of 'conversion' in Russia, the political significance of which became apparent soon after his mission was over.

\section{The Aftermath}

Henderson returned to England in late July on the same boat, as it happened, with four Russian socialists who were sent by the Petrograd Soviet to convince their western colleagues to attend the Stockholm Conference. ${ }^{68}$ The fact that the secretary of the British Labour party already agreed with them in principle made their mission infinitely easier. No one could challenge Henderson's prestige in the party executive, and if it came to a vote in conference, his view would decide the issue. In fact, that was precisely what did happen. On 25 July 1917, after he had reported on his trip to Russia in the presence of the Soviet's four emissaries, the Labour party NEC voted five to two to convene a special party conference on to August at which it would recommend 'to sanction the Party

64 'Mr Henderson's Views on Stockholm', The Times, 24 July 1917.

65 Wilton's letter to the editor of The Times, $3^{1}$ Dec. 1917 , signed 'Petrograd Correspondent '.

66 Rex Wade, 'Argonauts of Peace: The Soviet Delegation to Western Europe in the Summer of 1917 ', Slavic Review (Sept. 1967), Pp. 453-67. One of the delegates, Rusanov ' found Henderson impressed with the ideals of the Russian Revolution but depressed over what he considered the leadership's " impracticability", that is their lack of concern over strikes and disorders and other matters which he considered serious and wished to discuss ', p. 459. 
being represented at the Stockholm Conference '. ${ }^{67}$ Henderson then went to Paris with MacDonald for consultations with the French socialists, who had declared for Stockholm on 15 July. Just before the special conference on 9 August, the Labour party NEC reaffirmed its earlier decision with the qualification that the invitation to attend 'be accepted on condition that the Conference be consultative and not mandatory'. .8

The next day Henderson told the special Labour party conference in London why he had changed his mind. He reminded them that 'before I went to Russia some ten or twelve weeks ago I was opposed to the holding of an international conference '. On his arrival in Petrograd, he said, he had lost no time in informing the Petrograd Soviet of this fact. Since he knew that they had no intention of renouncing the conference, there were three courses which Henderson saw as available to him. One was a complete refusal of their request to attend the conference; the second was complete acceptance, and the third was to work to convert the conference into a consultation. After he saw conditions in Russia and how desperate the situation really was, he could not in conscience advocate the first course; he dismissed the second, and set his sights on the third.

Henderson concentrated his argument on the possibility of an outright rejection of the Soviet's request for the support of British Labour in its quest for peace. To have slammed the door in the Soviet's face, as it were, 'would have been', he believed, 'about the most fatal position that I could have taken up, either in a government capacity or as the representative of the great British Labour Movement '. ${ }^{\circ 9}$ Why?

The reason is simple. In my opinion, our case has never been properly stated and is certainly not properly understood to this day in Russia, and to have point blank refused to consider the question would have done incalculable harm.

During his mission, Henderson also encountered

not only confused but prejudiced ideas against the great Labour Movement, because of the mistaken notion of our attitude in supporting the war. Our objects have been perverted, and these perversions I found were being utilised to the full by enemy agents. ${ }^{70}$

Presumably, like Lenin, for example. And since he knew 'that a conference had become inevitable, owing to the determination of the Russians', to reject

67 Labour party NEC minutes, 25 July 1917. The Russians argued that the Conference could not be postponed beyond 22 August due to the Swedish and Russian elections at the end of August and September, respectively. Henderson probably argued in the terms he used in a letter to the American Labour leader, J. P. Frey, cited in H. M. Pelling, America and the British Left (1950), p. III: ' When in Russia I became aware that as far as the Russian democracy was concerned they were determined to have a conference if possible, and decided to advise my Executive to send delegates.'

68 Labour party NEC minutes, 9 Aug. 1917. The vote was nine to five. The minority wanted to leave the decision up to the conference without instructions.

69 Labour Party Annual Report, 1918, p. 47.

70 Ibid. p. 48. 
the proposal would have been to play right into the extremists' hands. They would then have had additional support if the Russian socialists alone met the neutral and central powers at Stockholm. Hence, 'after great thought', he concluded that 'British representatives should attend the Conference' as long as its resolutions were not binding on the participants. ${ }^{71}$ Above all, in considering this issue, he asked the delegates to

remember poor struggling Russia whose great miracle we welcomed with such delight a few weeks ago, and of whom it was universally admitted that it had done the finest thing that had ever been done during the whole War. Let us remember poor Russia, and if we cannot give the newest Democracy, the infant of Democracies, all she asks, I beseech you not to give her an entire point blank refusal. ${ }^{72}$

The resolution to go to Stockholm was passed by more than a three to one majority.

The political consequences of this decision were far-reaching. A few hours after the vote was taken, the cabinet decided 'Not to permit British representation at the Conference' and determined to expel Henderson from the government. ${ }^{73}$ His resignation was tendered and accepted the following morning. ${ }^{74}$

Although the Labour party did not leave the coalition at this time, the Stockholm incident was an important precipitating factor in its internal development. When Arthur Henderson spoke to the special conference and advocated attendance at Stockholm, the step he asked the party to take was, in effect, to begin a new political life.

Only after Petrograd did his commitment to a socialist policy to help end the war outweigh his sense of obligation to Lloyd George and the cabinet. ${ }^{75} \mathrm{His}$ experiences in Russia thus prepared the way for his decision to assert Labour's independence, by the adoption of a foreign policy of which he knew the government disapproved.

After his return from Russia, Henderson knew that a political collision was inevitable. He told the cabinet on I August of the importance which the Russian foreign secretary, Tereshchenko, attributed to the conference and on his (Henderson's) support for it. The only question which remained open was whether he would personally attend, and he told his colleagues that he had not yet decided. ${ }^{76}$ But his determination to see a British Labour delegation at Stockholm could not have been in doubt.

Henderson also knew that the British Government's views about Russia had changed to indifference after the failure of the Kornilov offensive. There was

71 Ibid. pp. 48-9.

72 Ibid. p. 5 I.

${ }^{73}$ Cab. 23/3, no. 2II (I, 5), io Aug. 1917, 6.15 P.m. Curzon, Milner, Bonar Law, Carson, and Lloyd George attended.

74 Cab. 23/3, no. 212 (I), II Aug. 1917, II a.m.

75 Cf. Mary Hamilton, Arthur Henderson, p. 164: 'By far the most important long-range result ' of the trip to Russia was the development of his 'international outlook, before dim and rather conventional, now gradually became vivid and personal and never again left him'.

76 Cab. 23/3, 202, I Aug. I9I7. 
no reason by August I9I7 why Lloyd George should tolerate a socialist peace offensive. The cabinet decided, therefore, on 8 August, that since the influence in Russia of the Petrograd Soviet 'was steadily declining', they would allow the discussion of foreign affairs only through the regular diplomatic channels. Hence 'the attendance of British delegates in Stockholm was', in their opinion, 'less important than formerly'. Furthermore, they made the pointed and condescending suggestion that it would be

more conducive to the maintenance of good relations between the British Government and the Labour Party, that the working men themselves should refuse to attend rather than that the Government should announce their decision and thereby appear to dictate to the Labour Party. ${ }^{77}$

Like any other social or political inferior, the 'working men' could choose to differ, of course, but they would have to be prepared to take the consequences.

Henderson chose not to tell the Labour party Conference of the strong objections to Stockholm or, despite the disingenuous wording, the explicit command of the cabinet for its rejection. He was no longer prepared to carry out Lloyd George's orders, and he had no intention of contributing to the further intimidation of labour which the prime minister had practised so successfully in the past. At the same time, he did not want to obscure the central issue by making the vote one of disapproval or approval of the government. A very different matter was at stake for which the cabinet had little sympathy - namely, the fate of the socialist revolution in Russia. Henderson's new political perspective precluded his return to the subservient role he had played earlier in the war. The development of his political ideas preconditioned the thrust for power and not the other way around. ${ }^{78}$

After his visit to Russia, Arthur Henderson acknowledged Labour's obligation as well as its right even in wartime to act from its own particular standpoint and in the light of its interests, which, as in the case of Stockholm, were international in scope. Without the shackles of government responsibility, he put his new convictions into practice in the task of reorganizing the Labour party.

Henderson was convinced by mid-1917 that the war had radically changed not only his but also popular ideas about politics. The Labour party had to be restructured, therefore, to reflect what he called ' the new democratic conscious-

${ }^{77}$ Cab. 23/3, 207 (5), 8 Aug. 1917.

78 The importance of the Russian visit for Henderson's attitude raises serious doubts about the argument of Samuel Beer in Modern British Politics (1960), ch. v, about the reconstruction of the Labour party. To discuss British political ideas in 1917 without mentioning the Russian Revolution, let alone Henderson's thoughts about it, is to invite distortion. Beer's mistake is that he failed to separate in his analysis the reasons for the ratification of the constitution by the trade union movement from the reasons for the formulation of the party constitution in the first place. His argument (p. I49) that 'The adoption of socialism as an ideology was functional to [the Labour Party's] choice for political independence' may explain the first, but it does not explain the second part of the problem. 
ness and the new social consciousness which have come to birth in the long agony of the present struggle $\cdot .^{79}$

It was 'a fact of enormous importance', he believed, that the advance in popular political thought 'synchronises' with the extension of the franchise. ${ }^{80}$ With the added support of millions of new electors, Henderson insisted, the Labour party could now 'prove that political methods are effective' to achieve the sweeping social changes which, he believed, were bound to come. In fact, the party had to show 'that the Democratic State of to-morrow can be established without an intervening period of violent upheaval and dislocation '. ${ }^{81}$

To make of the Labour party a moderate socialist alternative to extra-parliamentary action or even revolution itself was all the more important, Henderson argued, because so many men ' have become habituated to thoughts of violence' during the war. The legacy of his experience in Russia may be seen in this passage from a pamphlet he wrote in late 1917 to explain the reconstruction of the Labour party. ' Never before', he insisted,

have we had such vast numbers of the population skilled in the use of arms, disciplined, inured to danger, accustomed to act together under orders. When the war ends this country and every other will be flooded with hardy veterans of the great campaigns. Among them will be thousands of men who have exercised authority over their fellows in actual warfare, and who will be capable of assuming leadership again if insurrectionary movements come into existence. We may be warned by a perception of these facts that if barricades are indeed likely to be erected in our streets they will be manned by men who have learned how to fight and not by ill-disciplined mobs unversed in the use of modern weapons, likely to be easily overcome by trained troops. Revolution, if revolution is indeed to be forced upon democracy, will be veritable civil war ... this is the alternative that unmistakably confronts us if we turn aside from the path of ordered social change by constitutional means. ${ }^{82}$

Henderson issued this ominous warning shortly after the November revolution in Russia.

Just as he had supported the provisional government in Petrograd as the leftist alternative to Bolshevism, so he advocated a few months later the reconstruction of the Labour party with an ideological base as the bulwark of the British parliamentary system. Without his approval no plan for reorganization could have emerged from the NEC. But with the change in his view, Henderson joined Sidney Webb and Ramsay MacDonald in the NEC during the last year of the war to create the outline of a national party with a socialist programme on internal and international affairs.

19 Arthur Henderson, The Aims of Labour (Manchester, I918), p. Io.

80 Ibid. p. I3.

81 Ibid. pp. 6r-2.

82 Ibid. p. 59. Cf. also his other comments on the reconstruction of the party: 'The Need for Democratic Solidarity', Herald, I Dec. 1917; 'The New Labour Party Constitution', Fabian News, Jan. 1918; 'The Outlook for Labour', Contemporary Review (Feb. 1918), Pp. 121-30; and Labour Party Annual Report, 1918, pp. 98-100. 
On 26 September a joint sub-committee of the Labour party NEC and the parliamentary committee of the Trades Union Congress was formed to secure, after the failure to convene the Stockholm conference, ' a working agreement as to Peace and War Aims between the working-class of the Allied nations '. On this question, and on all others related to foreign policy, Henderson, MacDonald and Webb were authorized to act for the executive of the Labour party. ${ }^{83}$ The final memorandum which Webb drew up on their behalf was discussed by the executive on 24 October, adopted on 12 December and affirmed two weeks later at a special conference as the official position of the united labour movement. ${ }^{84}$

At the NEC meeting of 26 September at which the same three men were delegated to work out a labour foreign policy, Henderson also

presented a Memorandum proposing the reorganization of the Party with a view to a wider extension of membership, the strengthening and development of local parties in the constituencies, together with the promotion of a larger number of candidatures and the suggestion that a Party programme should be adopted.

The executive then appointed a sub-committee to consider the proposal. Webb, MacDonald and Henderson were the key men in the group. ${ }^{85}$ On Io October, a draft of the new constitution was circulated to the NEC, which chose this statement of the party's fourth object:

to secure for the producers by hand or by brain the full fruits of their industry, and the most equitable distribution thereof that may be possible, upon the basis of the common ownership of the means of production and the best obtainable system of popular administration and control of each industry or service. ${ }^{86}$

At this meeting as well, the same three were asked to prepare a report on reconstruction after the war. ${ }^{87}$ As in the case of the War Aims manifesto, Webb drafted the document, published in 1918 as Labour and the New Social Order. On I November 1917, the reorganization sub-committee of Henderson, MacDonald, Webb, Purdy, Middleton, the assistant secretary, and Peters, the party agent, reported to the executive. Among its suggestions was the establishment of permanent advisory committees to assist the NEC in its work. ${ }^{88}$

Thus by the beginning of the last year of the war, the Labour party NEC had adopted the fundamental ideas and structure of Labour politics which were to

83 Labour party NEC minutes, 26 Sept. 1917.

84 Ibid. 24 Oct., 12 Dec. 1917.

85 Ibid. 26 Sept. 1917.

86 Clause four, as it came to be known, was first submitted to the executive before Henderson returned from Russia in two forms. One limited the party's object to gaining 'The Common Ownership of All Monopolies and essential Raw Materials '. The other was the clause eventually adopted. Why two drafts were necessary is not clear, but after Henderson returned from Russia, a watered-down version of party objects was no longer needed. The conservative members of the NEC would vote the way he told them to. Labour party NEC minutes, draft constitution, 18-25 July igr7.

87 Labour party NEC minutes, ro Nov. r917.

88 Ibid. I Nov. 1917. 
dominate it for the next generation. In February 19I8, the new constitution was ratified in London by a special conference. Nine months later, the Labour party left the war with an ideological commitment which it could not have made and in a form which it could not have adopted a year earlier, let alone before the outbreak of the First World War. Henderson's role in this political transformation was a legacy of his mission to Russia in the spring of 1917. 